\title{
Büyükbaş hayvan ve tavuk gübreleri kaynaklı biyogaz potansiyeli; Adana ili örneği
}

\section{Biogas potential from cattle and poultry manure; Example of Adana province}

\author{
Müge ERKAN CAN \\ Çukurova Üniversitesi, Ziraat Fakültesi, Tarımsal Yapılar ve Sulama Bölümü, 01330, Adana \\ Sorumlu yazar (Corresponding author): M. Erkan Can, e-posta (e-mail): merkan@cu.edu.tr
}

MAKALE BİLGİSİ

Alınış tarihi 31 Ağustos 2020

Düzeltilme tarihi 09 Şubat 2021

Kabul tarihi 18 Mart 2021

\section{Anahtar Kelimeler:}

Ahır gübresi

Kümes gübresi

Biyogaz

Adana

Biyogaz üretimi
ÖZ

Hayvansal atıkların denetimsiz şekilde, hiçbir önlem alınmadan doğaya atılması hayvancılık işletmelerini "noktasal olmayan-sürekli kirletici kaynak" haline dönüștürür. Ancak uygun atık işleme yöntemi ile hayvansal atıklar hem değerli bir bitki besin elementi olacaktır hem de birtakım altyapı çalışmaları ile belirli bölgelerde yerel enerji ihtiyacının karşılanması için de kullanılabilir. Bu amaçla çalıșmada, Adana İli için büyükbaş hayvanlardan ve tavuklardan elde edilebilecek gübre ile potansiyel biyogaz üretim miktarları ve üretilen biyogazın kullanımı ile elde edilebilecek enerji değerleri hesaplanmıştır. Adana ili ve ilçeleri 2018 ve 2019 yılları için sırasıyla toplam büyükbaş hayvan sayısı 265430 baş ve 259684 baş ve toplam kümes hayvanı sayısı (etlik piliç ve yumurta tavuğu) 7236248 adet ve 6556620 adettir. Bu sayılara ait toplam faydalanabilir gübre miktarı yine 2018 ve 2019 yılları için sırası ile; büyükbaș hayvanlar için 1796280.4 ton $\mathrm{y}_{1} 1^{-1}$ ve 1785054.8 ton $\mathrm{y}_{1}{ }^{-1}$ kümes hayvanları için 476853.9 ton $\mathrm{yl}^{-1}$ ve 438219.5 ton $\mathrm{yll}^{-1}$ olarak hesaplanmıştır. Bu atıklardan elde edilebilecek toplam elektrik enerjisi miktarları ise büyükbaş hayvan atıkları için 342.32 $\mathrm{MWhe} \mathrm{yı1}^{-1}$, kümes hayvanları için ise $172.06 \mathrm{MWhe} \mathrm{yl}^{-1}$ olarak belirlenmiştir.

\section{ARTICLE INFO}

Received 31 August 2020

Received in revised form 09 February 2021

Accepted 18 March 2021

\section{Keywords:}

Barn manure

Poultry manure

Biogas

Adana

Biogas production

\begin{abstract}
Uncontrolled disposal of animal wastes without taking any precautions turns livestock enterprises into a "non-point-continuous polluting source". However, with the appropriate waste treatment method, animal wastes will be a valuable plant nutrient element and can be used to meet local energy needs in certain regions with some infrastructure works. For this purpose, in this study, the manure that can be obtained from cattle and chickens and potential biogas production amounts and the energy values that can be obtained by using this produced biogas were calculated for Adana Province. In Adana province and its districts for 2018 and 2019 respectively, the total number of cattle is 265430 heads and 259684 heads and the total number of poultry (broilers and laying hen) 7236248 and 6556620 . The total amount of usable animal manure for these numbers is also in 2018 and 2019, respectively; for cattle 1796280.4 tons year ${ }^{-1}$ and 1785054.8 tons year ${ }^{-1}$ and for poultry animals 476853.9 tons year ${ }^{-1}$ and 438219.5 tons year $^{-1}$. The total amount of electrical energy to be obtained from these wastes is determined as 342.32 MWhe year ${ }^{-1}$ for cattle waste and 172.06 MWhe year ${ }^{-1}$ for poultry.
\end{abstract}

\section{Giriş}

Gelişen teknoloji ve hızla artan nüfus ile birlikte hayvansal gıdalara talep artmakta, tüketim oranları her geçen gün yükselmektedir. Hızla artan üretim, düzenli olarak kontrol edilmez ve denetlenmez ise atıklar, doğal kaynaklar ve çevre bakımından zararlı bir kirletici kaynağı haline gelebilecektir. Bu yüzden çevre dostu, atık maddelerin geri dönüşümünü sağlayan yenilenebilir enerji kaynakları günümüzün ve geleceğin en önemli konuları arasındadır (Selimoğlu 2008). Tarımsal kökenli biyoyakıtlar, biyokütle enerjisi içerisinde hızla yaygınlaşan kaynakların başında gelmektedir. Biyoyakıtlar ve biyoyakıtlara dayalı enerji sistemleri teknolojik gelişmeler açısından önemli bir potansiyel sunmaktadır. Biyogaz, yenilenebilir enerjiler içerisinde bulunan biyokütle enerji kaynaklarından elde edilen yakıtlardandır (Avcıoğlu ve ark. 2011). Biyogaz organik maddelerin oksijensiz (anaerobik) şartlarda biyolojik parçalanması sonucu $\% 60$ ila $\% 80$ oranında metan ve karbondioksit gazlarından oluşmaktadır. Çeşitli organik maddelerin $\mathrm{CH}_{4}$ ve $\mathrm{CO}_{2}$ 'e dönüşümü karış1k mikrobiyolojik flora tarafından gerçekleştirilmektedir. Bu oksijensiz bozunmayı takiben metan gazı üç aşamalı bir işlem sonucunda oluşur. Bu işlem aşamalarını hidroliz, asit oluşumu, asetat oluşumu, ve metan oluşumu şeklinde dört ana başlık halinde özetleyebiliriz 
(Enerji ve Tabii Kaynaklar Bakanlığı 2020). Hayvansal atıklardan biyogaz üretmek ve çıkacak olan maddeleri de tekrar gübre olarak kullanmak mümkündür. Biyogaz eldesinden sonra çıkan maddeler gübre olarak kullanıldığında toprak verimi \%10 oranında artacak, biyogaz prosesi esnasında hayvan gübresinde bulunan yabancı ot tohumları çimlenme özelliğini kaybedecek ve hayvan gübresindeki rahatsız edici koku büyük oranda azalacaktır. Hayvansal atıklar içerdikleri kirleticiler ile yer altı sularını tehdit etmektedirler. Organik bileşenlerden üretilen biyogaz çok temiz bir yan ürüne sahip olduğundan bu tehditler biyogaz üretimi sayesinde ortadan kalkacaktır (Şenol ve ark. 2017).

Hayvan atıklarından biyogaz üretimi de bu konu içerisinde önemli bir yer tutar ve atıkların çevreye olan olumsuz etkilerinin azaltılmasına ve enerji üretiminde atıkların kaynak olarak kullanılabilmesine imkân sağlar. Biyogaz tesisinden yan ürün olarak elde edilen fermente gübre ise tarımda kullanılarak tarımsal verimin artışına katkıda bulunur. Büyükbaş hayvancılığın önemli bir geçim kaynağı olduğu ülkemizde biyogaz üretiminde kullanılmayan hayvansal ve bitkisel atıklar, çoğunlukla ya yakılmakta ya da işlenmeden tarım arazilerine gübre olarak verilmektedir. Kimi kırsal alanlarda ise atıkların yakılarak 1sınmada kullanılması nispeten daha yaygın olarak görülmektedir. Fakat bu şekildeki üretim ile istenilen özellikte 1S1 üretilememekte ve 1S1 üretiminden sonra atıkların gübre olarak kullanılması da mümkün olmamaktadır (Güç 2010).

Türkiye'de, 2020 yılı verilerine göre, toplam hayvansal atık miktarı 193878079 ton $\mathrm{yl}^{-1}$, bu atıkların enerji eşdeğeri 4385371 TEP $\mathrm{yl}^{-1}{ }^{-1}$ dır (BEPA 2020). Türkiye biyogaz potansiyeli bakımından önemli bir kaynağa sahip olmasına rağmen henüz bu kaynağın kullanım miktarı istenilen düzeyde değildir. Açılanan son resmi rakamlara göre Türkiye elektrik enerjisi kurulu gücünün kaynaklar bazında dağılımı incelendiğinde biyokütle oranının sadece \%1.5, elektrik üretiminde biyokütle enerjisinin payının ise sadece $\% 1.6$ olduğu görülmektedir (EMO 2020). Yenilenebilir kaynaklı kurulu gücün Türkiye toplam kurulu gücü içindeki pay1 \%48.6 ve bu oran içinde biyokütle kaynaklı enerji miktarı ise 791.3'tür (TEIAS 2019). Türkiye'de toplam kurulu gücü $1.092 \mathrm{MW}$ olan 100 adet "biyogaz, biyokütle, atık 1S1 ve pirolitik yağ enerji santrali bulunmaktadır. Ayrıca bu santrallerin kurulu güce oranı $\% 1.14$, yıllık elektrik üretimi yaklaşı $2.277 \mathrm{GWh}$ ve üretimin tüketime oranı ise \%0.76'dır (Enerji Atlas1 2019).

Gerek ülkemizde gerekse dünyada biyogaz üretimi, üretim şekilleri ve aşamaları ve üretilen biyogazın kullanımı ile ilgili çok sayıda araştırmalar yapılmıştır ve araştırmalarda materyal olarak hayvansal atıklar ve tarımsal atıklar kullanılmıştır. Bu çalışmaların, gerek ekonomik açıdan gerek hayvancılık bakımından gerekse mevcut durumun tespiti amaciyla, sürdürülmesi ve özellikle hayvancıllı̆ın yoğun olarak yapıldığ 1 bölgelerde daha detaylı incelemelerin yapılması gerekliliğ gayet açık olarak görülebilmektedir. Söz konusu nedenlerden yola çıkarak bu çalışmada, Adana ili ve ilçeleri için büyükbaş hayvancılıktan ve kümes hayvanlarından elde edilen gübreden üretilebilecek biyogaz potansiyelini ve bu biyogazdan üretilebilecek güç miktarını hesaplamak amaçlanmıştır.

\section{Materyal ve Yöntem}

Adana ili $35^{\circ}-38^{\circ}$ Kuzey enlemleri ile $34^{\circ}-36^{\circ}$ Doğu boylamları arasında ve Akdeniz Bölgesinde yer almaktadır. Güneyi 160 km'yi bulan Akdeniz kıyılarıyla sinırlanan ilin yüzölçümü $14030 \quad \mathrm{~km}^{2}$ 'dir. Şehir merkezinin denizden yüksekliği 23 m olan Adana'nın, Seyhan, Sarıçam, Çukurova, Yüreğir, Aladağ, Ceyhan, Feke, İmamoğlu, Karaisalı, Karataş, Kozan, Pozantı, Saimbeyli, Tufanbeyli ve Yumurtalık olmak üzere 15 ilçesi bulunmaktadır. İl genelinde, 15 ilçe arasında sosyo ekonomik yapı, sanayi ve yapılan tarım açısından bazı farklılıklar bulunmaktadır. Adana tarım ve hayvancılık yönünden Türkiye'nin en önemli şehirleri arasındadır. Türkiye'de en fazla hayvan yetiştiriciliği yapan iller arasında, Enerji İşleri Genel Müdürlüğü (EİGM) tarafindan hazırlanan ve Türkiye'nin biyokütle enerjisi potansiyelini ortaya koyan Biyokütle Enerjisi Potansiyeli Atlas1 (BEPA)'nda yapilan siralamada Adana 2. sirada yer almaktadır (Enerji ve Tabii Kaynaklar Bakanlığı 2019). Adana'da 4 adet kurulu biyogaz tesisi bulunmaktadır. Bu tesislerden ikisi Adana Büyükşehir Belediyesi'ne ait Adana Bat1 Atıksu Biyogaz Santrali ve Adana Doğu Atıksu Biyogaz Santrali olup her ikisi de 0.80 MW'llk enerji üretmektedir. Diğer tesislerden biri Pakmil Enerji'ye ait 1.76 MW enerji üreten Pakmil Biyokütle Santrali ve ITC Katı Atık Enerji'ye ait 16 MW güç üreten Sofulu Çöplüğü Biyogaz Santrali'dir.

Adana ili ve ilçeleri için 2018 ve 2019 yıllarına ait büyükbaş ve kümes hayvanı sayıları devlet kurumlarına ait veri tabanlarından (TUIK 2018 ve TUIK 2019) derlenerek ilgili tablolardaki hesaplamalarda materyal olarak kullanılmıştır. Bu belirlemelerden sonra hayvanlar; büyükbaş hayvancılık için süt sığırı, besi sığırı ve genç hayvan, kümes hayvanları için et ve yumurta tavuğu olacak şekilde sınıflandırılmıştır. Hayvanlardan elde edilecek potansiyel gübre miktarının hesaplanması için hayvan türlerine göre birim gübre üretim miktarları $(\mathrm{kg}$ hayvan gün ${ }^{-1}$ ) için katsayı kabulleri ve yaş gübreden elde edilebilecek metan miktarının hesabı amacıyla gübrenin kuru (katı) madde ve uçucu kuru madde oranlarına ait kabuller yapılmıştır. Türkiye'de hayvan gübresinden biyogaz üretim potansiyeli konusunda yapılan çalışmalarda, erişilebilir faydalı gübre miktarı teknik biyogaz potansiyeli olarak tanımlanmıştır. Bu bağlamda; birim hayvan için gübre üretimi miktarları, hayvanların barınaklarında kalma süresi dikkate alınarak belirlenen gübreye erişilebilirlik değerleri, gübrenin kuru madde ve uçucu kuru madde oranları ve gübreden metan üretim oranına ait değerler kullanılmıştır. Hesaplamalarda kabul edilen tüm katsayı ve oranlar Çizelge 1'de verilmiştir (Ekinci ve ark. 2010, Yokuş ve Onurbaş Avcioğlu 2012, Onurbaş Avcioğlu ve Türker 2012, Onurbaş Avcioğlu ve Türker 2013, Türk ve ark. 2015, Tinmaz Köse 2017, Dağtekin ve ark. 2019, Salihoğlu ve ark. 2019, Yağlı ve Koç 2019). Biyogaz potansiyeli hesaplanırken literatürden faydalanılarak uyarlanan aşağıdaki eşitlikler kullanılmıştır (Dağtekin ve ark. 2019, Yağlı ve Koç 2019). Bu eşitlikler dışında enerji değerleri birim dönüşümleri için standart birim çevirici katsayılardan faydalanılmıştır.

Eşitlik 1: TYG= YG.S.365

TYG: Yıllık toplam yaş gübre miktarı $\left(\mathrm{kg} \mathrm{y}^{\mathrm{y}} \mathrm{l}^{-1}\right), \mathrm{S}$ : Hayvan say1s1

YG: Birim hayvan başına üretilen günlük gübre miktarı $(\mathrm{kg}$ gün ${ }^{-1}$ hayvan)

Eşitlik 2: TFYG= TYG.T

TFYG: Hayvanların barınakta kalma süreleri dikkate alınarak hesaplanan yıllık toplam faydalanılabilir yaş gübre miktarı $\left(\mathrm{kg} \mathrm{y}_{1}{ }^{-1}\right)$, T: Toplanabilir faydalı gübre oranı (\%). 
Çizelge 1. Hayvan gübreleri ile ilgili kabuller

Table 1. Admissions regarding animal manure

\begin{tabular}{|c|c|c|c|c|c|}
\hline Hayvan Türü & $\begin{array}{c}\text { Birim Hayvan için } \\
\text { Ortalama Gübre Üretimi } \\
\left(\mathrm{kg} \text { hayvan-gün }{ }^{-1}\right)\end{array}$ & $\begin{array}{c}\text { Yaş Gübredeki Uçucu } \\
\text { Katı Madde Oranı } \\
\%\end{array}$ & $\begin{array}{c}\text { Kuru Madde } \\
\text { Oranı } \\
\%\end{array}$ & $\begin{array}{c}\text { Metan Üretim Oranı } \\
\left(\mathrm{m}^{3} \mathrm{CH}_{4} \mathrm{~kg}^{-1} \mathrm{UKM}\right)\end{array}$ & $\begin{array}{c}\text { Kullanılabilirlik } \\
\%\end{array}$ \\
\hline Süt Sı̆̆ırı & 43.00 & 83.36 & 17.5 & 0.18 & 65 \\
\hline Besi Sığırı & 29.00 & 84.65 & 12.5 & 0.33 & 50 \\
\hline Genç Yavru* & 2.48 & 44.23 & 4.00 & 0.33 & 65 \\
\hline Et Tavuğu & 0.19 & 77.27 & 20.00 & 0.35 & 99 \\
\hline Yumurta Tavuğu & 0.13 & 75.00 & 18.75 & 0.35 & 99 \\
\hline
\end{tabular}

\section{Eşitlik 3: FGTKM= TFYG.YGKM}

FGTKM: Yıllık toplam kuru madde miktarı $\left(\mathrm{kg} \mathrm{y} \mathbf{l}^{-1}\right)$, YGKM: Kat1 madde oran1 (\%)

\section{Eşitlik 4: TUKM= FGTKM.UKM}

TUKM: Yaş gübre içerisindeki yıllık toplam uçucu katı madde miktarı $\left(\mathrm{kg} \mathrm{y}^{-1} \mathrm{l}^{-1}\right)$

UKM: Uçucu kuru madde oranı (\%)

$$
\text { Eşitlik 5: MMETAN= TUKM.MM }
$$

M METAN: Toplanabilir faydalı gübreden elde edilebilecek toplam ylllik metan $\left(\mathrm{m}^{3} \mathrm{CH}_{4} \mathrm{yll}^{-1}\right)$

MM: Birim uçucu katı madde miktarı başına üretilecek metan miktarıdır. Hayvanlardan üretilen yıllık toplam biyogazın enerji miktarı hesaplanırken metan içeriği \%60 olan biyogaz için enerji değeri $22.7 \mathrm{MJ} \mathrm{m}^{-3}$ ve metan gazının enerji değeri 36 $\mathrm{MJ} \mathrm{m}^{-3}$ olarak alınmıştır (Görmüş 2018).

Eşitlik 6: QM= MMETAN.HMETAN

Qм: Metan gazından 1 yılda üretilebilecek enerji ( $\left.\mathrm{MJ} \mathrm{yl1}^{-1}\right)$

HMETAN: Metan gazının enerji değeri (36 $\left.\mathrm{MJ} \mathrm{m}^{-3}\right)$

Metan gazının bir CHP motorunda yakılarak elektrik üretilmesi sonucu elde edilecek elektrik miktarı hesaplanırken CHP motorunun elektriksel verimi (\%35) ve metan gazının enerji değeri $\left(10 \mathrm{kWh} \mathrm{m}^{-3}\right)$ kullanılmıştır.

\section{Bulgular ve Tartışma}

Elde edilen 2018 y1lı ve 2019 yılı hayvan sayıları verilerine göre, Adana ili ve ilçelerinde toplamda 2018 y1lı için 265430 adet büyükbaş ve 7236248 adet tavuk (etlik piliç ve yumurta tavuğu); 2019 yılı için ise 259684 adet büyükbaş ve 6556620 adet tavuk (etlik piliç ve yumurta tavuğu) bulunmaktadır. Bu bağlamda öncelikle, Adana ili ve ilçelerinde mevcut olan hayvanların 2018 ve 2019 yılları için hayvansal atık gübre miktarı incelenmiştir. Toplanabilir faydalı gübre miktarı, gübre içerisindeki \% katı madde miktarı uçucu katı madde miktarı hesaplanarak Çizelge 2'de ve Çizelge 3'de özetlenmiştir. Hesaplanan hayvansal atık miktarları kullanılarak biyogazdan enerji üretimine ilişkin değerler her ilçe için bulunmuştur. Hayvansal gübrelerden elde edilebilecek metan üretimi ve enerji değerleri büyükbaş hayvanlar için ve kümes hayvanları için ayrı ayrı Çizelge 4 ve Çizelge 5 içerisinde gösterilmektedir. İldeki hayvan sayılarına göre faydalanabilir gübre miktarı 2018 ve 2019 yılları için sırası ile; büyükbaş hayvanlar için 1796280.4 ton ${\mathrm{y} 1 l^{-1}}^{-1}$ ve 1785054.8 ton $\mathrm{yll}^{-1}$ kümes hayvanları için 476853.9 on $\mathrm{y}^{1} l^{-1}$ ve 438219.5 ton $\mathrm{y}^{-1}{ }^{-1}$ olarak hesaplanmıştır. $\mathrm{Bu}$ atıklardan elde edilecek toplam elektrik enerjisi miktarları ise büyükbaş hayvan atıkları için $342.32 \mathrm{MWhe} \mathrm{y}^{-1}{ }^{-1}$, kümes

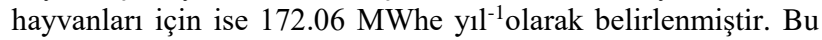
atıklardan elde edilecek toplam elektrik enerjisi miktarları büyükbaş hayvan atıkları için $342.32 \mathrm{MWhe} \mathrm{yl}^{-1}$, kümes hayvanları için ise $172.06 \mathrm{MWhe}_{\mathrm{y}} \mathrm{l}^{-1}$ olarak belirlenmiştir. Yıllar itibariyle elektrik enerjisi değerleri, büyükbaş hayvanlar için 2018 y1lı 171.23 $\mathrm{MWhe} \mathrm{yil}^{-1}, 2019 \mathrm{y}_{11} 171.09 \mathrm{MWhe} \mathrm{y}^{-1}$

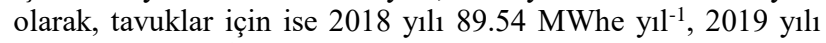
82.52 MWhe $\mathrm{yl}^{-1}$ olarak hesaplanmıştır.

Akbulut ve Dikici (2004), çalışmalarında, büyükbaş hayvanlardan 462600 ton $\mathrm{y}^{-1}{ }^{-1}$, kümes hayvanlarından ise 163049.7 ton $\mathrm{y}^{1} 1^{-1}$ gübre elde edileceğini hesaplamışlardır. Biyogaz üretimi sonuçları aynı sıra ile $15265800 \mathrm{~m}^{3} \mathrm{y}^{-1}$ $12717876 \mathrm{~m}^{3} \mathrm{yll}^{-1}$ olarak ve bu üretimin elektrik enerjisi eşdeğerleri de $196573 \mathrm{kWh}$ gün $^{-1}$ ve $182562 \mathrm{kWh}$ gün ${ }^{-1}$ olarak verilmektedir. Ilgar (2016), hayvan varlığına göre Çanakkale biyogaz potansiyelinin tespitine yönelik yaptığı çalışmada, büyükbaş hayvan gübre üretim miktarını 720493 ton $\mathrm{y}^{1^{-1}}$, biyogazı $23776269 \mathrm{~m}^{3} \mathrm{yl}^{-1}$, kanatlı hayvan için gübre üretim miktarını 637406 ton $\mathrm{y}^{-1}{ }^{-1}$, biyogazı $49717668 \mathrm{~m}^{3} \mathrm{y}_{1}^{-1}$ olarak hesaplamıştır. $\mathrm{Bu}$ rakamlara ait elektrik enerjisi eşdeğeri büyükbaş hayvan gübresinden $306158 \mathrm{kWh}$ gün $^{-1}$, kanatlı hayvan gübresinden ise $640196 \mathrm{kWh}$ gün $^{-1}$ olarak bildirilmektedir. Erzincan ili hayvansal atıklardan elde edilebilir yıllık biyogaz miktarının araştırıldığı çalışmada büyükbaş hayvanlardan 352187 ton $\mathrm{y}^{l^{-1}}$, kanatl hayvanlardan 40078 ton $\mathrm{y} \mathrm{l}^{-1}$ gübre üretimi olduğu ve toplam biyogaz potansiyelinin il genelinde $15511011 \mathrm{~m}^{3} \mathrm{y}^{-1}$ olarak hesaplandığ 1 belirtilmiş, elektrik üretimi miktarı ise $38025864 \mathrm{kWhe} \mathrm{yll}^{-1}$ olarak bildirilmiştir (Kurnuç Seyhan ve Badem 2018). Mersin il genelinde, 10 yıllık dönemi kapsayan çalışmada, toplam büyükbaş ve kanatlı hayvan sayıları sırasıyla yaklaşı olarak 1.06 ve 104.26 milyon; elde edilen gübre miktarları yaklaşık olarak büyükbaş için 3.83 milyon ton ve kanatlı için 2.29 milyon ton olarak hesaplanmıştır. Toplam biyogaz büyükbaş için $63331270 \mathrm{~m}^{3}$ ve elektrik enerjisi $297656970 \mathrm{kWh}$; kanatl için biyogaz $177124595 \mathrm{~m}^{3}$ elektrik enerjisi $832485598 \mathrm{kWh}$ olarak bildirilmiştir (Demir ve ark. 2018). Yetiş ve ark. (2019)'nın Bitlis ilinin ve ilçelerinin hayvan sayısından oluşan atık miktarlarından biyogaza dönüştürülme potansiyelini araştırdıkları çalışmada, biyogaz değerleri büyükbaş için (82406 adet) $17570030.48 \mathrm{~m}^{3} \mathrm{yl}^{-1}$ ve kanatlı (tavuk) için (601555 adet) $175621.13 \mathrm{~m}^{3} \mathrm{yll}^{-1}$ olarak hesaplanmıştır.

Çalışmalara ilişkin potansiyel elektrik enerjisi değerleri bakımından inceleme yapıldığında, farklı çalışmalarda seçilen birimler birbirine dönüştürülerek kıyaslama yapılmış ve neticede hayvan sayısı ile sonuçlar arasında paralellik olduğu gözlenmiştir. Ayrıca, bu konuda yapılan farklı çalışmalar incelendiğinde de, yoğun oranda büyükbaş hayvan kaynaklı 
Çizelge 2. Büyükbaş hayvancılıkta potansiyel biyogaz üretimi için gübre ile ilişkili miktarlar Table 2. Amounts associated with manure for potential biogas production in cattle breeding

\begin{tabular}{|c|c|c|c|c|c|c|c|c|c|c|c|c|}
\hline \multirow[t]{2}{*}{ İlçe } & \multicolumn{3}{|c|}{$\begin{array}{c}\text { Toplanabilir } \\
\text { Faydalı Gübre Miktarı } \\
\left(\text { (ton yıl }^{-1}\right)\end{array}$} & \multicolumn{3}{|c|}{$\begin{array}{c}\text { Katı Madde } \\
\text { Miktarı (ton yıl }{ }^{-1} \text { ) }\end{array}$} & \multicolumn{3}{|c|}{$\begin{array}{l}\text { Uçucu Katı Madde } \\
\text { Miktarı (ton yıl' }\end{array}$} & \multicolumn{3}{|c|}{$\begin{array}{c}\text { İlçelere Göre UKM } \\
\text { Dağılım Oranları } \\
(\%)\end{array}$} \\
\hline & Süt Sığırı & $\begin{array}{c}\text { Besi } \\
\text { S1ğır1 }\end{array}$ & $\begin{array}{c}\text { Genç } \\
\text { Hayvan* }\end{array}$ & Süt Sığırı & $\begin{array}{c}\text { Besi } \\
\text { Sığırı } \\
\end{array}$ & $\begin{array}{c}\text { Genç } \\
\text { Hayvan* }\end{array}$ & $\begin{array}{c}\text { Süt } \\
\text { S1ğırı }\end{array}$ & $\begin{array}{c}\text { Besi } \\
\text { Siğırı }\end{array}$ & $\begin{array}{c}\text { Genç } \\
\text { Hayvan* }\end{array}$ & $\begin{array}{c}\text { Süt } \\
\text { Sığırı }\end{array}$ & $\begin{array}{c}\text { Besi } \\
\text { Sı ̆̆̆ırı } \\
\end{array}$ & $\begin{array}{c}\text { Genç } \\
\text { Hayvan* }^{*}\end{array}$ \\
\hline \multicolumn{13}{|c|}{2018 Yılı } \\
\hline 1 & 29248.4 & 3466.6 & 966.1 & 5118.5 & 433.3 & 38.6 & 4266.8 & 366.8 & 17.1 & 2.00 & 1.18 & 2.47 \\
\hline 2 & 168481.9 & 19598.1 & 3672.7 & 29484.3 & 2449.8 & 146.9 & 24578.1 & 2073.7 & 65.0 & 11.52 & 6.65 & 9.40 \\
\hline 3 & 137856.2 & 13405.9 & 1786.9 & 24124.8 & 1675.7 & 71.5 & 20110.5 & 1418.5 & 31.6 & 9.43 & 4.55 & 4.57 \\
\hline 4 & 98191.8 & 10960.8 & 3239.6 & 17183.6 & 1370.1 & 129.6 & 14324.2 & 1159.8 & 57.3 & 6.71 & 3.72 & 8.29 \\
\hline 5 & 80604.0 & 16549.6 & 2419.4 & 14105.7 & 2068.7 & 96.8 & 11758.5 & 1751.2 & 42.8 & 5.51 & 5.62 & 6.19 \\
\hline 6 & 177296.2 & 8706.2 & 4955.3 & 31026.8 & 1088.3 & 198.2 & 25864.0 & 921.2 & 87.7 & 12.12 & 2.95 & 12.69 \\
\hline 7 & 8967.3 & 1000.3 & 259.5 & 1569.3 & 125.0 & 10.4 & 1308.2 & 105.8 & 4.6 & 0.61 & 0.34 & 0.66 \\
\hline 8 & 45101.9 & 2577.4 & 947.9 & 7892.8 & 322.2 & 37.9 & 6579.5 & 272.7 & 16.8 & 3.08 & 0.87 & 2.43 \\
\hline 9 & 292780.0 & 26838.3 & 8508.6 & 51236.5 & 3354.8 & 340.3 & 42710.7 & 2839.8 & 150.5 & 20.02 & 9.11 & 21.78 \\
\hline 10 & 65648.3 & 128062.6 & 1570.4 & 11488.4 & 16007.8 & 62.8 & 9576.8 & 13550.6 & 27.8 & 4.49 & 43.45 & 4.02 \\
\hline 11 & 82573.0 & 6679.1 & 2797.7 & 14450.3 & 834.9 & 111.9 & 12045.7 & 706.7 & 49.5 & 5.65 & 2.27 & 7.16 \\
\hline 12 & 50549.7 & 4482.7 & 1478.6 & 8846.2 & 560.3 & 59.1 & 7374.2 & 474.3 & 26.2 & 3.46 & 1.52 & 3.79 \\
\hline 13 & 153444.5 & 47918.3 & 4145.1 & 26852.8 & 5989.8 & 165.8 & 22384.5 & 5070.4 & 73.3 & 10.49 & 16.26 & 10.61 \\
\hline 14 & 26983.6 & 2021.7 & 729.6 & 4722.1 & 252.7 & 29.2 & 3936.4 & 213.9 & 12.9 & 1.85 & 0.69 & 1.87 \\
\hline 15 & 44755.1 & 2471.6 & 1581.6 & 7832.1 & 308.9 & 63.3 & 6528.9 & 261.5 & 28.0 & 3.06 & 0.84 & 4.05 \\
\hline$\sum$ & 1462482.1 & 294739.3 & 39059.0 & 255934.4 & 36842.4 & 1562.4 & 213346.9 & 31187.1 & 691.0 & 100 & 100 & 100 \\
\hline \multicolumn{13}{|c|}{2019 Yılı } \\
\hline 1 & 26167.5 & 3212.5 & 932.6 & 4579.3 & 401.6 & 37.3 & 3817.3 & 339.9 & 16.5 & 1.82 & 1.02 & 2.66 \\
\hline 2 & 168879.8 & 19947.4 & 3724.4 & 29554.0 & 2493.4 & 149.0 & 24636.2 & 2110.7 & 65.9 & 11.77 & 6.34 & 10.64 \\
\hline 3 & 167186.3 & 21127.7 & 2570.6 & 29257.6 & 2641.0 & 102.8 & 24389.1 & 2235.6 & 45.5 & 11.65 & 6.71 & 7.34 \\
\hline 4 & 99110.0 & 11151.3 & 3324.3 & 17344.3 & 1393.9 & 133.0 & 14458.2 & 1179.9 & 58.8 & 6.91 & 3.54 & 9.49 \\
\hline 5 & 87398.4 & 15575.8 & 1657.5 & 15294.7 & 1947.0 & 66.3 & 12749.7 & 1648.1 & 29.3 & 6.09 & 4.95 & 4.73 \\
\hline 6 & 155444.1 & 10230.4 & 4653.5 & 27202.7 & 1278.8 & 186.1 & 22676.2 & 1082.5 & 82.3 & 10.83 & 3.25 & 13.29 \\
\hline 7 & 11844.2 & 1159.1 & 313.0 & 2072.7 & 144.9 & 12.5 & 1727.8 & 122.6 & 5.5 & 0.83 & 0.37 & 0.89 \\
\hline 8 & 55375.1 & 2905.6 & 1536.3 & 9690.6 & 363.2 & 61.5 & 8078.1 & 307.4 & 27.2 & 3.86 & 0.92 & 4.39 \\
\hline 9 & 203494.3 & 14236.8 & 4385.2 & 35611.5 & 1779.6 & 175.4 & 29685.7 & 1506.4 & 77.6 & 14.18 & 4.52 & 12.52 \\
\hline 10 & 94631.4 & 158187.5 & 1730.4 & 16560.5 & 19773.4 & 69.2 & 13804.8 & 16738.2 & 30.6 & 6.59 & 50.24 & 4.94 \\
\hline 11 & 88643.0 & 8431.0 & 2727.7 & 15512.5 & 1053.9 & 109.1 & 12931.2 & 892.1 & 48.3 & 6.18 & 2.68 & 7.79 \\
\hline 12 & 48927.6 & 2884.4 & 1115.0 & 8562.3 & 360.6 & 44.6 & 7137.6 & 305.2 & 19.7 & 3.41 & 0.92 & 3.18 \\
\hline 13 & 138223.5 & 39577.3 & 3610.9 & 24189.1 & 4947.2 & 144.4 & 20164.0 & 4187.8 & 63.9 & 9.63 & 12.57 & 10.31 \\
\hline 14 & 27544.7 & 2752.1 & 841.4 & 4820.3 & 344.0 & 33.7 & 4018.2 & 291.2 & 14.9 & 1.92 & 0.87 & 2.40 \\
\hline 15 & 62322.5 & 3466.6 & 1894.0 & 10906.4 & 433.3 & 75.8 & 9091.6 & 366.8 & 33.5 & 4.34 & 1.10 & 5.41 \\
\hline$\sum$ & 1435192.4 & 314845.5 & 35016.8 & 251158.7 & 39355.7 & 1400.7 & 209365.9 & 33314.6 & 619.5 & 100 & 100 & 100 \\
\hline
\end{tabular}

1: Aladă̆, 2: Ceyhan, 3: Feke, 4: Karaisalı, 5: Karataş, 6: Kozan, 7: Pozantı, 8: Saimbeyli, 9: Sarıçam, 10: Seyhan, 11: Tufanbeyli, 12: Yumurtalık 13: Yüreğir, 14: Çukurova, 15: İmamoğlu, *: Buzağı ve diğerleri. 
Çizelge 3. Kümes hayvancılığında potansiyel biyogaz üretimi için gübre ile ilişkili miktarlar

Table 3. Amounts associated with manure for potential biogas production in poultry

\begin{tabular}{|c|c|c|c|c|c|c|c|c|}
\hline \multirow[t]{2}{*}{ İlçe } & \multicolumn{2}{|c|}{$\begin{array}{c}\text { Toplanabilir Faydalı Gübre } \\
\text { Miktarı (ton yıl }^{-1} \text { ) }\end{array}$} & \multicolumn{2}{|c|}{$\begin{array}{c}\text { Katı Madde } \\
\left.\text { Miktarı (ton yıl }{ }^{-1}\right)\end{array}$} & \multicolumn{2}{|c|}{$\begin{array}{l}\text { Uçucu Katı Madde } \\
\text { Miktarı (ton yıl }\end{array}$} & \multicolumn{2}{|c|}{$\begin{array}{c}\text { İlçelere Göre UKM } \\
\text { Dağılım Oranları (\%) }\end{array}$} \\
\hline & Et Tavuğu & Yumurta Tavuğu & Et Tavuğu & Yumurta Tavuğu & Et Tavuğu & Yumurta Tavuğu & Et Tavuğu & Yumurta Tavuğu \\
\hline \multicolumn{9}{|c|}{2018 Yilı } \\
\hline 1 & 20253.7 & 140.9 & 4050.7 & 26.4 & 3130.0 & 19.8 & 4.67 & 0.33 \\
\hline 2 & 85820.6 & 14656.4 & 17164.1 & 2748.1 & 13262.7 & 2061.1 & 19.79 & 33.89 \\
\hline 3 & 0.0 & 837.6 & 0.0 & 157.0 & 0.0 & 117.8 & 0.00 & 1.94 \\
\hline 4 & 34235.6 & 339.5 & 6847.1 & 63.7 & 5290.8 & 47.7 & 7.90 & 0.78 \\
\hline 5 & 0.0 & 250.1 & 0.0 & 46.9 & 0.0 & 35.2 & 0.00 & 0.58 \\
\hline 6 & 3089.5 & 1879.0 & 617.9 & 352.3 & 477.5 & 264.2 & 0.71 & 4.34 \\
\hline 7 & 4462.7 & 79.4 & 892.5 & 14.9 & 689.7 & 11.2 & 1.03 & 0.18 \\
\hline 8 & 0.0 & 808.0 & 0.0 & 151.5 & 0.0 & 113.6 & 0.00 & 1.87 \\
\hline 9 & 52247.6 & 10804.4 & 10449.5 & 2025.8 & 8074.3 & 1519.4 & 12.05 & 24.98 \\
\hline 10 & 107426.1 & 8086.4 & 21485.2 & 1516.2 & 16601.6 & 1137.1 & 24.78 & 18.70 \\
\hline 11 & 0.0 & 681.1 & 0.0 & 127.7 & 0.0 & 95.8 & 0.00 & 1.57 \\
\hline 12 & 0.0 & 704.6 & 0.0 & 132.1 & 0.0 & 99.1 & 0.00 & 1.63 \\
\hline 13 & 94402.7 & 171.5 & 18880.5 & 32.1 & 14589.0 & 24.1 & 21.77 & 0.40 \\
\hline 14 & 21970.1 & 117.4 & 4394.0 & 22.0 & 3395.3 & 16.5 & 5.07 & 0.27 \\
\hline 15 & 9695.3 & 3693.8 & 1939.1 & 692.6 & 1498.3 & 519.4 & 2.24 & 8.54 \\
\hline$\sum$ & 433603.8 & 43250.1 & 86720.8 & 8109.4 & 67009.1 & 6082.0 & 100 & 100 \\
\hline \multicolumn{9}{|c|}{2019 Yilı } \\
\hline 1 & 20253.7 & 0.0 & 4050.7 & 0.0 & 3130.0 & 0.0 & 4.91 & 0.00 \\
\hline 2 & 81661.5 & 1670.0 & 16332.3 & 313.1 & 12620.0 & 234.8 & 19.80 & 6.46 \\
\hline 3 & 0.0 & 838.0 & 0.0 & 157.1 & 0.0 & 117.8 & 0.00 & 3.24 \\
\hline 4 & 34654.3 & 387.5 & 6930.9 & 72.7 & 5355.5 & 54.5 & 8.40 & 1.50 \\
\hline 5 & 0.0 & 203.2 & 0.0 & 38.1 & 0.0 & 28.6 & 0.00 & 0.79 \\
\hline 6 & 3089.5 & 1785.1 & 617.9 & 334.7 & 477.5 & 251.0 & 0.75 & 6.90 \\
\hline 7 & 4462.7 & 28.2 & 892.5 & 5.3 & 689.7 & 4.0 & 1.08 & 0.11 \\
\hline 8 & 0.0 & 793.9 & 0.0 & 148.9 & 0.0 & 111.6 & 0.00 & 3.07 \\
\hline 9 & 44283.4 & 5637.1 & 8856.7 & 1056.9 & 6843.6 & 792.7 & 10.74 & 21.80 \\
\hline 10 & 107427.9 & 9497.0 & 21485.6 & 1780.7 & 16601.9 & 1335.5 & 26.05 & 36.73 \\
\hline 11 & 0.0 & 688.2 & 0.0 & 129.0 & 0.0 & 96.8 & 0.00 & 2.66 \\
\hline 12 & 0.0 & 702.3 & 0.0 & 131.7 & 0.0 & 98.8 & 0.00 & 2.72 \\
\hline 13 & 85906.4 & 192.6 & 17181.3 & 36.1 & 13276.0 & 27.1 & 20.83 & 0.74 \\
\hline 14 & 21970.1 & 129.2 & 4394.0 & 24.2 & 3395.3 & 18.2 & 5.33 & 0.50 \\
\hline 15 & 8650.7 & 3307.1 & 1730.1 & 620.1 & 1336.9 & 465.1 & 2.10 & 12.79 \\
\hline$\sum$ & 412360.2 & 25859.3 & 82472.0 & 4848.6 & 63726.1 & 3636.5 & 100 & 100 \\
\hline
\end{tabular}

1: Aladă̆, 2: Ceyhan, 3: Feke, 4: Karaisalı, 5: Karataș, 6: Kozan, 7: Pozantı, 8: Saimbeyli, 9: Sarıçam, 10: Seyhan, 11: Tufanbeyli, 12: Yumurtalık,

13: Yüreğir, 14: Çukurova, 15: İmamoğlu. 
Çizelge 4. Büyükbaş hayvan gübreleri için metan üretimi ve enerji değerleri

Table 4. Methane production and energy values for cattle manure

\begin{tabular}{|c|c|c|c|c|c|c|c|c|c|c|c|c|}
\hline \multirow{2}{*}{ İlçe } & \multicolumn{3}{|c|}{$\begin{array}{c}\text { Metan Üretimi } \\
\left(1000 \mathrm{~m}^{3} \mathrm{CH}_{4} \mathrm{yll}^{-1}\right)\end{array}$} & \multicolumn{3}{|c|}{$\begin{array}{c}\text { Enerji Değeri } \\
\left(\text { GJ yul }^{-1}\right)\end{array}$} & \multicolumn{3}{|c|}{$\begin{array}{l}\text { Enerji Değeri } \\
(\text { TEP yıl }\end{array}$} & \multicolumn{3}{|c|}{$\begin{array}{c}\text { Elektrik Enerjisi Değeri } \\
\left(\mathrm{MWhe} \mathrm{yll}^{-1}\right)\end{array}$} \\
\hline & Süt Sığırı & Besi Sığırı & $\begin{array}{c}\text { Genç } \\
\text { Hayvan* }\end{array}$ & Süt Sığırı & Besi Sığırı & $\begin{array}{c}\text { Genç } \\
\text { Hayvan* }\end{array}$ & Süt Sığırı & $\begin{array}{l}\text { Besi } \\
\text { Sığırı }\end{array}$ & $\begin{array}{c}\text { Genç } \\
\text { Hayvan }\end{array}$ & $\begin{array}{c}\text { Süt } \\
\text { Sığırı }\end{array}$ & $\begin{array}{l}\text { Besi } \\
\text { Siğır }\end{array}$ & $\begin{array}{l}\text { Genç } \\
\text { Hayvan }\end{array}$ \\
\hline \multicolumn{13}{|c|}{2018 yılı } \\
\hline 1 & 768.02 & 121.05 & 5.64 & 27648.60 & 4357.68 & 203.06 & 660.34 & 104.08 & 4.85 & 2.69 & 0.42 & 0.02 \\
\hline 2 & 4424.07 & 684.33 & 21.44 & 159266.35 & 24635.88 & 771.92 & 3803.83 & 588.39 & 18.44 & 15.48 & 2.40 & 0.08 \\
\hline 3 & 3619.88 & 468.11 & 10.43 & 130315.84 & 16851.92 & 375.57 & 3112.39 & 402.48 & 8.97 & 12.67 & 1.64 & 0.04 \\
\hline 4 & 2578.36 & 382.73 & 18.91 & 92820.99 & 13778.26 & 680.91 & 2216.89 & 329.07 & 16.26 & 9.02 & 1.34 & 0.07 \\
\hline 5 & 2116.53 & 577.88 & 14.13 & 76195.18 & 20803.78 & 508.52 & 1819.80 & 496.87 & 12.15 & 7.41 & 2.02 & 0.05 \\
\hline 6 & 4655.51 & 304.00 & 28.93 & 167598.54 & 10944.10 & 1041.52 & 4002.83 & 261.38 & 24.88 & 16.29 & 1.06 & 0.10 \\
\hline 7 & 235.47 & 34.93 & 1.51 & 8476.85 & 1257.41 & 54.54 & 202.46 & 30.03 & 1.30 & 0.82 & 0.12 & 0.01 \\
\hline 8 & 1184.30 & 90.00 & 5.53 & 42634.97 & 3239.99 & 199.23 & 1018.27 & 77.38 & 4.76 & 4.15 & 0.31 & 0.02 \\
\hline 9 & 7687.93 & 937.14 & 49.68 & 276765.66 & 33737.11 & 1788.34 & 6610.12 & 805.76 & 42.71 & 26.91 & 3.28 & 0.17 \\
\hline 10 & 1723.82 & 4471.71 & 9.17 & 62057.46 & 160981.44 & 330.07 & 1482.15 & 3844.79 & 7.88 & 6.03 & 15.65 & 0.03 \\
\hline 11 & 2168.23 & 233.22 & 16.33 & 78056.42 & 8396.02 & 588.03 & 1864.26 & 200.53 & 14.04 & 7.59 & 0.82 & 0.06 \\
\hline 12 & 1327.35 & 156.53 & 8.63 & 47784.73 & 5635.05 & 310.77 & 1141.26 & 134.58 & 7.42 & 4.65 & 0.55 & 0.03 \\
\hline 13 & 4029.21 & 1673.22 & 24.20 & 145051.47 & 60235.81 & 871.23 & 3464.33 & 1438.64 & 20.81 & 14.10 & 5.86 & 0.08 \\
\hline 14 & 708.55 & 70.60 & 4.26 & 25507.69 & 2541.43 & 153.35 & 609.21 & 60.70 & 3.66 & 2.48 & 0.25 & 0.01 \\
\hline 15 & 1175.20 & 86.30 & & 42307.08 & 3106.93 & & 1010.44 & 74.20 & 7.94 & 4.11 & 0.30 & 0.03 \\
\hline$\sum$ & 38402.44 & 10291.74 & 228.04 & 1382487.81 & 370502.81 & 8209.46 & 33018.58 & 8848.88 & 196.07 & 134.41 & 36.02 & 0.80 \\
\hline \multicolumn{13}{|c|}{2019 yılı } \\
\hline 1 & 687.1 & 112.2 & 5.4 & 24736.2 & 4038.3 & 196.0 & 590.79 & 96.45 & 4.68 & 2.40 & 0.39 & 0.02 \\
\hline 2 & 4434.5 & 696.5 & 21.7 & 159642.5 & 25075.0 & 782.8 & 3812.81 & 598.88 & 18.70 & 15.52 & 2.44 & 0.08 \\
\hline 3 & 4390.0 & 737.7 & 15.0 & 158041.6 & 26558.6 & 540.3 & 3774.58 & 634.31 & 12.90 & 15.37 & 2.58 & 0.05 \\
\hline 4 & 2602.5 & 389.4 & 19.4 & 93688.9 & 14017.8 & 698.7 & 2237.61 & 334.79 & 16.69 & 9.11 & 1.36 & 0.07 \\
\hline 5 & 2294.9 & 543.9 & 9.7 & 82617.9 & 19579.6 & 348.4 & 1973.20 & 467.63 & 8.32 & 8.03 & 1.90 & 0.03 \\
\hline 6 & 4081.7 & 357.2 & 27.2 & 146941.6 & 12860.2 & 978.1 & 3509.47 & 307.14 & 23.36 & 14.29 & 1.25 & 0.10 \\
\hline 7 & 311.0 & 40.5 & 1.8 & 11196.4 & 1457.0 & 65.8 & 267.41 & 34.80 & 1.57 & 1.09 & 0.14 & 0.01 \\
\hline 8 & 1454.1 & 101.5 & 9.0 & 52346.2 & 3652.5 & 322.9 & 1250.21 & 87.23 & 7.71 & 5.09 & 0.36 & 0.03 \\
\hline 9 & 5343.4 & 497.1 & 25.6 & 192363.7 & 17896.4 & 921.7 & 4594.31 & 427.43 & 22.01 & 18.70 & 1.74 & 0.09 \\
\hline 10 & 2484.9 & 5523.6 & 10.1 & 89455.3 & 198850.0 & 363.7 & 2136.50 & 4749.22 & 8.69 & 8.70 & 19.33 & 0.04 \\
\hline 11 & 2327.6 & 294.4 & 15.9 & 83794.4 & 10598.1 & 573.3 & 2001.30 & 253.12 & 13.69 & 8.15 & 1.03 & 0.06 \\
\hline 12 & 1284.8 & 100.7 & 6.5 & 46251.4 & 3625.9 & 234.3 & 1104.64 & 86.60 & 5.60 & 4.50 & 0.35 & 0.02 \\
\hline 13 & 3629.5 & 1382.0 & 21.1 & 130663.0 & 49750.8 & 758.9 & 3120.68 & 1188.22 & 18.13 & 12.70 & 4.84 & 0.07 \\
\hline 14 & 723.3 & 96.1 & 4.9 & 26038.1 & 3459.5 & 176.8 & 621.88 & 82.63 & 4.22 & 2.53 & 0.34 & 0.02 \\
\hline 15 & 1636.5 & 121.0 & 11.1 & 58913.6 & 4357.7 & 398.1 & 1407.06 & 104.08 & 9.51 & 5.73 & 0.42 & 0.04 \\
\hline$\sum$ & 37685.9 & 10993.8 & 204.4 & 1356690.8 & 395777.4 & 7359.9 & 32402.46 & 9452.53 & 175.78 & 131.90 & 38.48 & 0.72 \\
\hline
\end{tabular}

1: Aladă̆, 2: Ceyhan, 3: Feke, 4: Karaisalı, 5: Karataş, 6: Kozan, 7: Pozantı, 8: Saimbeyli, 9: Sarıçam, 10: Seyhan, 11: Tufanbeyli, 12: Yumurtalık, 13: Yüreğir, 14: Çukurova, 15: İmamoğlu, *: Buzağı ve diğerleri. 
Çizelge 5. Tavuk gübreleri için metan üretimi ve enerji değerleri

Table 5. Methane production and energy values for poultry manure

\begin{tabular}{|c|c|c|c|c|c|c|c|c|}
\hline \multirow[t]{2}{*}{ İlçe } & \multicolumn{2}{|c|}{$\begin{array}{c}\text { Metan Üretimi } \\
\left(1000 \mathrm{~m}^{3} \mathrm{CH}_{4} \mathrm{yll}^{-1}\right)\end{array}$} & \multicolumn{2}{|c|}{$\begin{array}{c}\begin{array}{c}\text { Enerji Değeri } \\
\left(\text { GJ yll }{ }^{-1}\right)\end{array} \\
\end{array}$} & \multicolumn{2}{|c|}{$\begin{array}{l}\text { Enerji Değeri } \\
\left(\text { TEP yıl }{ }^{-1}\right)\end{array}$} & \multicolumn{2}{|c|}{$\begin{array}{c}\text { Elektrik Enerjisi Değeri } \\
\left(\text { MWhe } \text { yll }^{-1}\right)\end{array}$} \\
\hline & Et Tavuğu & Yumurta Tavuğu & Et Tavuğu & Yumurta Tavuğu & Et Tavuğu & Yumurta Tavuğu & Et Tavuğu & Yumurta Tavuğu \\
\hline \multicolumn{9}{|c|}{2018 yılı } \\
\hline 1 & 1095.50 & 6.94 & 39438.0 & 249.7 & 941.92 & 5.96 & 3.83 & 0.02 \\
\hline 2 & 4641.95 & 721.37 & 167110.3 & 25969.2 & 3991.17 & 620.23 & 16.25 & 2.52 \\
\hline 3 & 0.00 & 41.22 & 0.0 & 1484.1 & 0.00 & 35.44 & 0.00 & 0.14 \\
\hline 4 & 1851.77 & 16.71 & 66663.6 & 601.5 & 1592.16 & 14.37 & 6.48 & 0.06 \\
\hline 5 & 0.00 & 12.31 & 0.0 & 443.2 & 0.00 & 10.59 & 0.00 & 0.04 \\
\hline 6 & 167.11 & 92.48 & 6016.0 & 3329.4 & 143.68 & 79.52 & 0.58 & 0.32 \\
\hline 7 & 241.38 & 3.91 & 8689.7 & 140.7 & 207.54 & 3.36 & 0.84 & 0.01 \\
\hline 8 & 0.00 & 39.77 & 0.0 & 1431.6 & 0.00 & 34.19 & 0.00 & 0.14 \\
\hline 9 & 2826.02 & 531.78 & 101736.7 & 19144.0 & 2429.82 & 457.22 & 9.89 & 1.86 \\
\hline 10 & 5810.57 & 398.00 & 209180.6 & 14328.0 & 4995.95 & 342.20 & 20.34 & 1.39 \\
\hline 11 & 0.00 & 33.53 & 0.0 & 1206.9 & 0.00 & 28.83 & 0.00 & 0.12 \\
\hline 12 & 0.00 & 34.68 & 0.0 & 1248.5 & 0.00 & 29.82 & 0.00 & 0.12 \\
\hline 13 & 5106.15 & 8.44 & 183821.3 & 303.8 & 4390.29 & 7.26 & 17.87 & 0.03 \\
\hline 14 & 1188.34 & 5.78 & 42780.2 & 208.1 & 1021.74 & 4.97 & 4.16 & 0.02 \\
\hline 15 & 524.41 & 181.80 & 18878.6 & 6544.9 & 450.89 & 156.32 & 1.84 & 0.64 \\
\hline$\sum$ & 23453.20 & 2128.71 & 844315.1 & 76633.7 & 20165.16 & 1830.28 & 82.09 & 7.45 \\
\hline \multicolumn{9}{|c|}{2019 yılı } \\
\hline 1 & 1095.50 & 0.00 & 39438.02 & 0.00 & 941.92 & 0.00 & 3.83 & 0.00 \\
\hline 2 & 4416.99 & 82.19 & 159011.57 & 2958.99 & 3797.74 & 70.67 & 15.46 & 0.29 \\
\hline 3 & 0.00 & 41.25 & 0.00 & 1484.91 & 0.00 & 35.46 & 0.00 & 0.14 \\
\hline 4 & 1874.42 & 19.07 & 67478.99 & 686.69 & 1611.63 & 16.40 & 6.56 & 0.07 \\
\hline 5 & 0.00 & 10.00 & 0.00 & 359.99 & 0.00 & 8.60 & 0.00 & 0.03 \\
\hline 6 & 167.11 & 87.86 & 6015.97 & 3162.92 & 143.68 & 75.54 & 0.58 & 0.31 \\
\hline 7 & 241.38 & 1.39 & 8689.73 & 49.94 & 207.54 & 1.19 & 0.84 & 0.00 \\
\hline 8 & 0.00 & 39.07 & 0.00 & 1406.67 & 0.00 & 33.60 & 0.00 & 0.14 \\
\hline 9 & 2395.25 & 277.45 & 86228.90 & 9988.17 & 2059.44 & 238.55 & 8.38 & 0.97 \\
\hline 10 & 5810.67 & 467.43 & 209183.95 & 16827.56 & 4996.03 & 401.90 & 20.34 & 1.64 \\
\hline 11 & 0.00 & 33.87 & 0.00 & 1219.39 & 0.00 & 29.12 & 0.00 & 0.12 \\
\hline 12 & 0.00 & 34.57 & 0.00 & 1244.36 & 0.00 & 29.72 & 0.00 & 0.12 \\
\hline 13 & 4646.59 & 9.48 & 167277.37 & 341.26 & 3995.16 & 8.15 & 16.26 & 0.03 \\
\hline 14 & 1188.34 & 6.36 & 42780.23 & 228.90 & 1021.74 & 5.47 & 4.16 & 0.02 \\
\hline 15 & 467.91 & 162.77 & 16844.71 & 5859.72 & 402.31 & 139.95 & 1.64 & 0.57 \\
\hline$\sum$ & 22304.15 & 1272.76 & 802949.45 & 45819.46 & 19177.20 & 1094.33 & 78.06 & 4.45 \\
\hline
\end{tabular}

1: Aladağ, 2: Ceyhan, 3: Feke, 4: Karaisalı, 5: Karataş, 6: Kozan, 7: Pozantı, 8: Saimbeyli, 9: Sarıçam, 10: Seyhan, 11: Tufanbeyli, 12: Yumurtalık, 13: Yüreğir, 14: Çukurova, 15: İmamoğlu.

gübre olmak üzere; elde edilen toplam yaş gübre miktarları, dolayısı ile biyogaz potansiyeli bakımından, Adana ili rakamlarından daha düşük veya yakın miktarlara sahip bölgeler için de biyogaz enerji santrali kurulumun isabetli olacağ 1 sonucuna ulaşılmıştır (Ergürer ve Okumuş 2010, Altıkat ve Çelik 2012, Çağlayan ve Koçer 2014, Baran ve ark. 2017, Kalaycı ve ark. 2019). Bunun yanı sıra, incelenen çalışmaların çoğunluğunda, hayvancılık işletmeleri atıklarından hesaplanan toplam biyogaz enerji miktarının il genelinde toplam enerji ihtiyacını karşılanamaya yetmeyeceği ancak mikro ölçekli bir işletmenin enerji ihtiyacını karşılayabileceği kanaatine varılmıștır.

Adana ilinde ve ilçelerinde 2018 ve 2019 yılları toplamı için hayvanlardan elde edilebilecek toplam gübre miktarlarına göre enerji dağılım haritaları çizilmiş ve büyükbaş hayvan gübrelerinden elde edilen enerji dăğlım haritası Şekil 1'de; kümes hayvanlarının gübrelerinden elde edilen enerji dağılım haritası ise Şekil 2'de verilmiştir. Dağılım haritaları ve grafikler incelendiğinde büyükbaş hayvanlar için toplam $3521.03 \mathrm{TJ} \mathrm{y1l}^{-1}$, kümes hayvanları için $1769.72 \mathrm{TJ}_{\mathrm{y} 11^{-1}}$ enerji potansiyeli elde edildiği görülmektedir. Kümes hayvancıllğg için ise söz konusu potansiyelin en yüksek Seyhan (449.52 TJ y1 $\left.{ }^{-1}\right)$, Ceyhan (355.05 $\left.\mathrm{TJ} \mathrm{yll}^{-1}\right)$, Yüreğir (351.74 TJ yıl' $\left.{ }^{-1}\right)$, Sarıçam (217.10 TJ $\mathrm{y} \mathrm{l}^{-1}$ ) ilçelerinde olduğu belirlenmiştir. Aynı zamanda düşük kümes hayvanı sayılarından ve coğrafi konumlarından dolayı Feke, Saimbeyli, Yumurtalık, Tufanbeyli ve Karataş ilçelerinde biyogaz üretim potansiyelinin olmadığı sonucuna varılabilir.

Kahramanmaraş il genelinde yapılan çalışmaya göre, yıllık toplam kullanılabilir katı gübre miktarı büyükbaş ve kanatlı hayvanlara göre sırasıyla yaklaşık 2006928 ton $\mathrm{yil}^{-1}$ ve 36810 ton $\mathrm{y}^{-1}{ }^{-1}$ dır. Hayvansal gübrelerden sağlanabilecek yıllık toplam biyogaz enerji değeri büyükbaş ve kanatlı hayvanlara göre sirasiyla 1430 TJ ve 62 TJ'dur (Aybek ve ark. 2015). Tınmaz Köse (2017), Trakya Bölgesi için hayvan gübrelerinden 


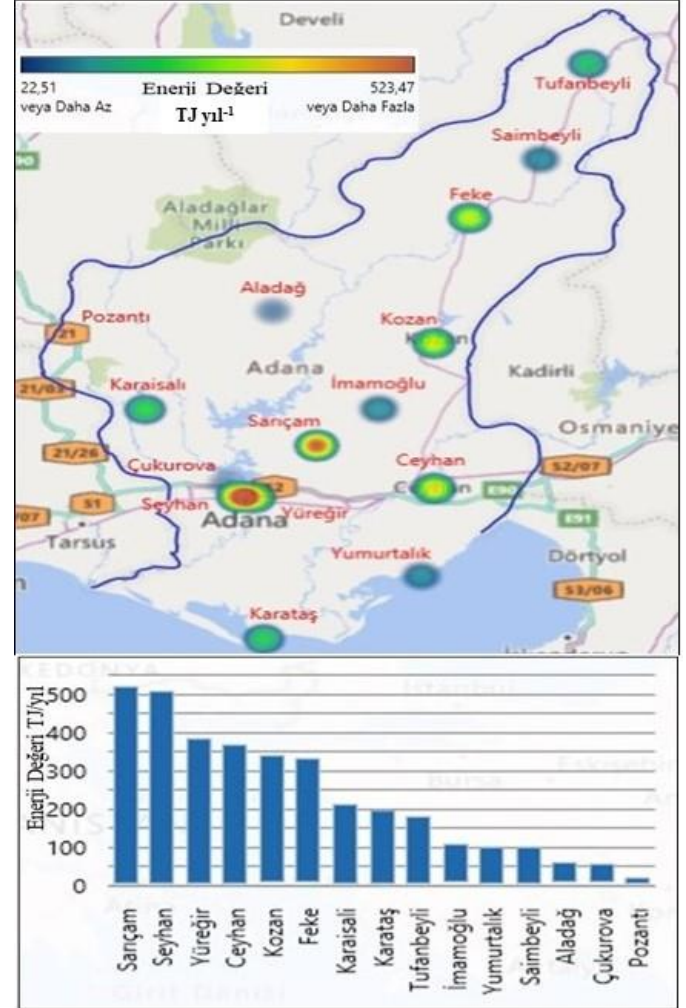

Şekil 1. Büyükbaş hayvan gübrelerinden elde edilecek biyogazın enerji değeri.

Figure 1. Energy value of biogas to be obtained from cattle manure.

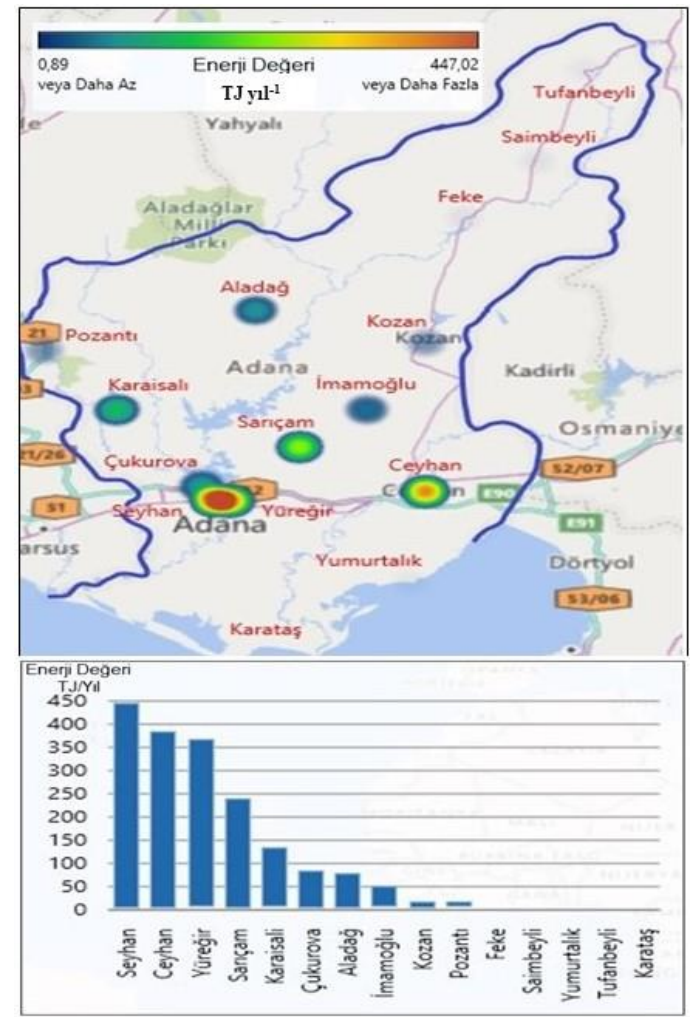

Şekil 2. Kümes hayvanlarının gübrelerinden elde edilecek biyogazın enerji değeri.

Figure 2. Energy value of biogas to be obtained from poultry manure. biyogaz enerji potansiyelini araştırmış ve Trakya Bölgesi'ndeki 2015 yılı hayvan sayılarını; büyükbaş 443057 adet, küçükbaş 1033578 adet ve kümes hayvanları 1445380 adet olarak belirlemiștir. $\mathrm{Bu}$ değerler baz alındığında hayvan gübrelerinden üretilebilecek biyogazın enerji eşdeğeri $2.42781 \mathrm{TJ}_{\mathrm{y} 11^{-1}}$ olarak haritalanmıştır. Dağtekin ve ark. 2019'nın Adana ili ve ilçelerini de kapsayan çalıșmalarında, etlik piliç için toplam 458345,54 ton $\mathrm{yll}^{-1}$ yaş gübre hesaplamışlar ve bu miktara ilişkin ilçe bazında üretilecek elektrik enerjisi potansiyelinin ise en yüksek Ceyhan, Yüreğir, Seyhan, Sarıçam ve Karaisalı ilçelerinde olduğunu vurgulamışlardır. Bu ilçelerdeki y1llık elektrik üretim miktarı ise sirasiyla $327.84 ; 280.21 ; 273.06 ; 132.99$ ve 128.87 MWhe olarak hesaplanmışıtır. Çalışmaların verileri karşılaştırıldığında etlik piliç kümesleri için Adana ilçeler bazındaki sıralamanın uyumlu olduğu ancak seçilen yöntem ve oranların farklı olması nedeniyle kümes için elde edilen sonuçların uyumlu bulunmadığ 1 söylenebilir. Bölgesel bazda enerji dağılımları incelendiğinde yine seçilen hayvan cinsi, bölgedeki hayvan sayısı ve katsayılar gibi faktörlerin büyük önem arz ettiği görülmüştür. Bu faktörlere dikkat ederek ve "il geneli - büyükbaş hayvan ve etlik piliç-yumurta tavuğu" olarak baz alındığında çalışma sonuçlarının literatür ile uyumlu olduğu söylenebilir.

Çalışma sonuçlarında büyükbaş hayvan gübresinden 2018 y1lı için $48922.22 \mathrm{~m}^{3} \mathrm{CH}_{4} \mathrm{y}^{1}{ }^{-1}, 2019$ y1lı için $48884.1 \mathrm{~m}^{3} \mathrm{CH}_{4}$ $\mathrm{y}^{-1}{ }^{-1}$ tavuk gübresinden ise 2018 y1lı için $25581.91 \mathrm{~m}^{3} \mathrm{CH}_{4} \mathrm{y}^{1} l^{-1}, 2019 \mathrm{y} 11$ için ise $23576.91 \mathrm{~m}^{3} \mathrm{CH}_{4} \mathrm{y}^{1-1}$ metan miktarı elde edilmiştir. Yağlı ve Koç (2019)'un hayvan gübresinden biyogaz üretim potansiyelini belirlemek için 2018 yılında yaptıkları çalışmada, Adana ilindeki çiftlik hayvanlarından elde edilen gübrenin anaerobik ayrışması ile yıllık ortalama biyogaz üretimi $88367.417 \mathrm{~m}^{3} \mathrm{CH}_{4} \mathrm{yl}^{-1}$ olarak ve bu biyogazın kullanımı ile yıllık yaklaşık elektrik enerjisi üretimi 309.286 $\mathrm{MWhe}^{\mathrm{y} 1 \mathrm{l}^{-1}}$ olarak hesaplamışlardır. Metan gazının $78745.94 \mathrm{~m}^{3}$ 'ünün toplam büyükbaş hayvanlardan ve $4786.38 \mathrm{~m}^{3}$ 'ünün ise toplam kanatl hayvanlardan üretilebileceği hesaplanmıştır. Her iki çalışmadan elde edilen sonuçların kıyaslanması ile hayvan sayısı, oranlar ve katsayıların aynı olması halinde elde edilen sonuçların büyük oranda benzer olduğu görülmektedir.

Geniş kapsamlı literatür çalışması yapılarak özetlenen araştırmalardan da görüldüğü üzere hayvansal gübreden elde edilebilecek biyogaz potansiyeli ve bu potansiyelin elektrik enerjisi eşdeğerleri; bölgede yürütülen hayvancıllk faaliyetlerinin yoğunluğu, seçilen hayvan cinsi ve hayvan sayısı gibi faktörler başta olmak üzere diğer birtakım etkenlere göre değişkenlik göstermektedir. Adana ilinin 15 ilçesinde yürütülen hayvancılık faaliyetleri tür, yoğunluk, türler arası dağılım gibi unsurlar açısından farklılık gösterdiği için ilçelerin biyogaz potansiyelleri de farklı bulunmuştur. Ancak hayvan sayılarının fazlalığından dolayı merkez ilçeler olan Sarıçam (523.47 $\mathrm{TJ}^{\mathrm{y}} \mathrm{yl}^{-}$ $\left.{ }^{1}\right)$, Seyhan $\left(512.04 \mathrm{TJ} \mathrm{yil}^{-1}\right)$, Yüreğir $\left(387.33 \mathrm{TJ} \mathrm{yl}^{-1}\right)$ ilçelerinin biyogaz üretim miktarları ve elde edilebilecek elektrik enerjisi eş değeri bakımından diğer ilçelere göre daha fazla potansiyele sahip olduğu görülmektedir.

\section{Sonuç ve Öneriler}

Biyogaz tesisi inşası veya biyogaz üretiminde süreklilik için, ekonomik, sosyal, çevresel faktörler ile bu başlıklarla ilişkili diğer tüm alt faktörlerin dikkatle incelenmesine ve bölge bazında detaylandırılarak değerlendirme yapılmasına ihtiyaç vardır. Biyogaz üretebilmek için en uygun hammadde, oran ve teknoloji seçilerek sistemin doğru şekilde işletilmesi 
sağlanmalıdır. Yapılacak projeler hakkında işletmecilerin katılımının sağlanması için gerekli teknik bilgilerin ve eğitimin verilmesi, kazanımlar hakkında bilgilendirme yapılması ve gerekirse destek olacak ekonomik teşviklerin sunulması faydalı olacaktır. Hayvancılık işletmelerindeki bu çalışmalar ve biyogaz üretimi aşamasına geçilebilmesi bölge ekonomisine önemli oranda katkı sağlayacaktır. Biyogaz üretiminin gerçekleştirilmesi ve hayvancılık işletmelerini dahil edecek şekilde yaygınlaştırılması ile insan, hayvan ve çevre için zararlı olan hayvansal atıkların değerlendirilmesi ve uygun atık yönetimi yapılmış olacaktır.

$\mathrm{Bu}$ çalışmada bulunan teorik miktarlar sadece Adana ilindeki biyogaz potansiyelini ve bu potansiyelin enerji eşdeğerini göstermektedir. Bölgedeki hayvansal atık potansiyeli göz önüne alındığında biyogaz gereklilikleri açısından önemli bir boşluk olduğu göze çarpmaktadır. Bu durum, Adana ve çevresinin gelişimini de dikkate alarak, başta merkez ilçeler olmak üzere Ceyhan ve Karaisalı ilçelerini de kapsayan yeni biyogaz tesislerinin gündeme gelmesi fikrini ortaya koymaktadır. Detaylı fizibilite çalışmalarıyla biyogaz hesabının yapıldığı yeni projeler ile ildeki biyogaz potansiyelinin değerlendirilmesi hem bölgenin enerji ihtiyacının karşılanmasına hem de hayvansal gübrenin çevreye daha az zararla kullanılabilir forma dönüştürülmesine olanak sağlayabilecektir. Biyogazın verimi ve yanıcılığı $\mathrm{CH}_{4}$ gazından kaynaklanmaktadır. Bu nedenle metan miktarları da önemli bir proje planlama kriteri olacaktır. Adana ili ve ilçeleri için büyükbaş, etlik piliç ve yumurta tavuğu gübrelerinden üretilen metan miktarları, ildeki biyogaz üretimi projelerinde değerlendirilmek için elverişlidir denilebilir. $\mathrm{Bu}$ rakamlara küçükbaş hayvan ve diğer kümes hayvanı gübreleri de eklendiğinde elde edilecek miktarlar artacaktır. Saha çalışmaları, atık miktarı tespitleri ve periyodik olarak yapılacak atık analizleri, atık maliyeti, ulaşım, alt yapı, uygulanacak teknoloji, ilk yatırım giderleri gibi unsurların biyogaz projelerinde dikkatle optimize edilmesi gerekmektedir. Bunun yanı sıra, farklı teorik kabullerin, oranların ve formüllerin toplam biyogaz hesabında farklı sonuçlar vereceği gerçeği göz önünde bulundurularak hesaplamalar yapılmalıdır.

\section{Teşekkür}

$\mathrm{Bu}$ çalışma Çukurova Üniversitesi Bilimsel Araştırma Projeleri Koordinasyon Birimi tarafindan FBA-2017-7450 nolu proje ile desteklenmiştir.

\section{Kaynaklar}

Akbulut A, Dikici A (2004) Elazığ ilinin biyogaz potansiyeli ve maliyet analizi. Doğu Anadolu Bölgesi Araştırmaları Dergisi 2(2): 36-41.

Altıkat S, Çelik A (2012) Iğdır ilinin hayvansal atık kaynaklı biyogaz potansiyeli. Iğdır Üniversitesi Fen Bilimleri Enstitüsü Dergisi 2(1): 61-66.

Avcıoğlu OA, Türker U, Atasoy DZ, Koçtürk D (2011) Tarımsal kökenli yenilenebilir enerjiler biyoyakıtlar. Nobel Akademik Yayıncılık.

Aybek A, Üçok S, Bilgili ME, İspir MA (2015) Kahramanmaraş İlinde bazı tarımsal atıkların biyogaz enerji potansiyelinin belirlenerek sayısal haritalarının oluşturulması. Uludağ Üniversitesi Ziraat Fakültesi Dergisi 29(2): 25-37.

Baran MF, Lüle F, Gökdoğan O (2017) Adıyaman ilinin hayvansal atıklardan elde edilebilecek enerji potansiyeli. Türk Tarım ve Doğa Bilimleri Dergisi 4(3): 245-249.

BEPA (2020) Enerji İşleri Genel Müdürlüğü veri tabanı https://bepa.enerji.gov.tr/. Erişim Ocak 2021.

Çağlayan GH, Koçer NN (2014) Muş ilinde hayvan potansiyelinin değerlendirilerek biyogaz üretiminin araştırılması. Muş Alparslan Üniversitesi Fen Bilimleri Dergisi 2(1): 215-220.

Dağtekin M, Aybek A, Bilgili E (2019) Adana ve Mersin'de bulunan etlik piliç kümeslerinde oluşan gübrenin biyogaz ve elektrik üretim potansiyelinin belirlenmesi. Çukurova Üniversitesi Mühendislik Mimarlık Fakültesi Dergisi 34(2): 9-22.

Demir B, Sağlam C, Çetin N, Büyükkılıç Beyzi S (2018). Mersin ilinin hayvansal atıklardan biyogaz ve elektrik enerjisi üretim potansiyeli. 3rd International Mediterranean Science and Engineering Congress, s. $1589-1591$.

Ekinci K, Kulcu R, Kaya D, Yaldiz O, Ertekin C, Ozturk H (2010) The prospective of potential biogas plants that can utilize animal manure in Turkey. Energy Exploration \& Exploitation 28(3): 187206.

EMO (2020) TMMOB Elektrik Mühendisleri Odası Türkiye Elektrik Enerjisi İstatistikleri https://www.emo.org.tr/. Erişim Ocak 2021.

Enerji Atlası (2019) https://www.enerjiatlasi.com/biyogaz/. Erişim Ocak 2021.

Enerji ve Tabii Kaynaklar Bakanlığı (2019) Yenilenebilir Enerji Genel Müdürlüğü, Türkiye Biyokütle Enerjisi Potansiyeli Atlası, http://bepa.yegm.gov.tr/. Erişim Nisan 2019.

Enerji ve Tabii Kaynaklar Bakanlığı (2020) https://www.enerji.gov.tr/trTR/Sayfalar/Biyokutle. Erişim Ocak 2020.

Ergürer HS, Okumuş F (2010) Cost and potential analysis of biogas in Eskisehir, Uludağ Üniversitesi Mühendislik-Mimarlık Fakültesi Dergisi 15(2): 155 .

Görmüş C (2018) Türkiye'deki hayvan gübrelerinin biyogaz enerji potansiyelinin belirlenmesi. Yüksek Lisans Tezi, Namık Kemal Üniversitesi Fen Bilimleri Enstitüsü, Tekirdağ.

Güç A (2010) Büyükbaş hayvan atığından biyogaz üretimi ve Uşak ili için çevresel etkilerinin değerlendirilmesi. Yüksek Lisans Tezi, Ege Üniversitesi Fen Bilimleri Enstitüsü Güneş Enerjisi Anabilim Dalı, Bornova-İzmir.

Ilgar R (2016) Hayvan varlığına göre Çanakkale biyogaz potansiyelinin tespitine yönelik bir çalışma. Doğu Coğrafya Dergisi 21(35): 89106.

Kalaycı E, Türker G, Çağlarer E (2019) Kırklareli ilinin hayvansal atık potansiyelinin biyogaz üretimi çerçevesinde değerlendirilmesi ve güncel yapının yorumlanması. Bitlis Eren Üniversitesi Fen Bilimleri Dergisi 8(4): 1489-1497.

Kurnuç Seyhan A, Badem A (2018) Erzincan ilindeki hayvansal atıkların biyogaz potansiyelinin araştırılması. APJES 6(1): 25-35.

Onurbaş Avcioğlu A, Türker U (2012) Status and potential of biogas energy from animal wastes in Turkey. Renew Sustain Energy Reviews 16(3): 1557-1561.

Onurbaş Avcıoğlu A, Türker Ç (2013) Türkiye'nin tavuk atıklarından biyogaz potansiyeli. Namik Kemal Üniversitesi Tekirdağ Ziraat Fakültesi Dergisi 10(1): 21-28.

Salihoğlu NK, Teksoy A, Altan K (2019) Büyükbaş ve küçükbaş hayvan atıklarından biyogaz üretim potansiyelinin belirlenmesi: Balıkesir ili örneği. Ömer Halisdemir Üniversitesi Mühendislik Bilimleri Dergisi 8(1): 31-47.

Selimoğlu S (2008) Büyükbaş hayvan dışkısından biyogaz üretimi. Yüksek Lisans Tezi, Gazi Üniversitesi Fen Bilimleri Enstitüsü Kimya Mühendisliği, Ankara.

Şenol H, Elibol EA, Açıkel Ü, Şenol M (2017) 2016'da Türkiye'de kanatlı hayvanlardan üretilebilecek biyogaz ve elektrik enerji potansiyeli. Bitlis Eren Üniversitesi Fen Bilimleri Dergisi 6(1): 111.

TEIAS (2019) Türkiye Elektrik İletim A.Ş, Elektrik İstatistikleri, "Türkiye Aylık Elektrik Enerjisi İstatistik Raporu 1" www.enerji.gov.tr. Erişim Ocak 2021. 
Tinmaz Köse E (2017) Trakya bölgesinde hayvan gübrelerinin biyogaz enerji potansiyelinin belirlenmesi ve sayısal haritaların olușturulması. Pamukkale Üniversitesi Mühendislik Bilimleri Dergisi 23(6): 762-772.

TUIK (2018) Türkiye İstatistik Kurumu 2018 yılı hayvancılık istatistikleri veri tabanı. http://www.tuik.gov.tr/PreTabloArama.do? metod=search\&araType=vt. Erişim Kasım 2019.

TUIK (2019) Türkiye İstatistik Kurumu 2019 yılı hayvancılık istatistikleri veri tabanı. http://www.tuik.gov.tr/PreTabloArama.do? metod=search\&araType=vt. Erişim Kasım 2019.

Türk H, Nacar Koçer N, Kaya Hanay Ö (2015) Elazığ İlinde faaliyet gösteren tavuk çiftliklerindeki atıklardan elde edilebilecek enerji potansiyelinin değerlendirilmesi. Fırat Üniversitesi Mühendislik Bilimleri Dergisi 27(1): 1-7.

Yağlı H, Koç Y (2019) Hayvan gübresinden biyogaz üretim potansiyelinin belirlenmesi: Adana ili örnek hesaplama. Cukurova Üniversitesi Mühendislik Mimarlık Fakültesi Dergisi 34(3): 35-48.

Yetiş DA, Gazigil L, Yetiş R, Çelikezen B (2019) Hayvansal atık kaynaklı biyogaz potansiyeli: Bitlis örneği. Academic Platform Journal of Engineering and Science 7(1): 68-72.

Yokuş İ, Onurbaş Avcıoğlu A (2012) Sivas ilindeki hayvansal atıklardan biyogaz potansiyelinin belirlenmesi. Tarımsal Mekanizasyon Ulusal Kongresi, Samsun, s. 488-498. 